\section{Container Medium pH in a Pine Tree Substrate Amended with Peatmoss and Dolomitic Limestone Affects Plant Growth}

\author{
Brian E. Jackson ${ }^{1,4}$ \\ North Carolina State University, Department of Horticulture, 114 Kilgore \\ Hall, Campus Box 7609, Raleigh, NC 27695
}

Robert D. Wright ${ }^{2}$

Department of Horticulture, Virginia Polytechnic Institute and State University, 301 Saunders Hall, Blacksburg, VA 24061

\section{Nazim Gruda ${ }^{3}$}

Institute for Horticultural Science, Faculty for Agriculture and Horticulture, Humboldt University of Berlin, Lentzeallee 55/57, 14195 Berlin, Germany

Additional index words. fertilization, growing media, loblolly pine, Pelargonium $\times$ hortorum, Pinus taeda, plant nutrition, Tagetes erecta, wood substrate

\begin{abstract}
This work was conducted to evaluate the effect of limestone additions to pine tree substrate (PTS) and PTS amended with peatmoss on pH and plant growth. 'Inca Gold' marigold (Tagetes erecta L.) and 'Rocky Mountain White' geranium (Pelargonium $\times$ hortorum L.H. Bailey) were grown in three PTSs-100\% PTS, PTS plus $25 \%$ peatmoss (v/v), and PTS plus $50 \%$ peatmoss (v/v) — made from freshly harvested loblolly pine trees (Pinus taeda L.) chipped and hammermilled through a 4.76- $\mathrm{mm}$ screen and a peatmoss/ perlite $(4: 1 \mathrm{v} / \mathrm{v} ; \mathrm{PL})$ control. Each substrate was amended with various rates of dolomitic limestone and used to grow marigolds in $10-\mathrm{cm}$ square (l-L) plastic containers and geraniums in round $15-\mathrm{cm}(1.25-\mathrm{L})$ plastic containers in a glasshouse. Regardless of limestone rate, $\mathrm{pH}$ was highest in $\mathbf{1 0 0} \%$ PTS and decreased with peat additions with PL having the lowest $\mathrm{pH}$. As percent peat increased from $25 \%$ to $50 \%$, more limestone was required to adjust $\mathrm{pH}$ to a particular level showing that PTS is more weakly buffered against pH change than peatmoss. Adding limestone did not increase the growth of marigold in $100 \%$ PTS, but additions of limestone did increase growth of marigold when grown in PTS containing peatmoss or in PL. Geranium growth was higher in PTS containing peatmoss $(25 \%$ or $50 \%)$ and PL than in $100 \%$ PTS at all limestone rates. This research demonstrates that PTS produced from freshly harvested pine trees has an inherently higher $\mathrm{pH}$ than $\mathrm{PL}$, and the additions of peatmoss to PTS require $\mathrm{pH}$ adjustment of the substrate for optimal plant growth.
\end{abstract}

Most all ornamental greenhouse crops (Nelson, 2003) and all house/foliage plants are grown in containers. The basis for most container substrates is peatmoss, aged pine bark (PB), and more recently coconut coir.

Received for publication 17 July 2009. Accepted for publication 15 Sept. 2009

The research was funded in part by the American Floral Endowment, Horticultural Research Institute, Virginia Agricultural Council, the Virginia Nursery and Landscape Association, and the Virginia Tobacco Commission.

Use of trade names does not imply endorsement of the products named nor criticism of similar ones not mentioned.

${ }^{1}$ Former Graduate Research Assistant. Currently Assistant Professor, Department of Horticultural Science, North Carolina State University, Raleigh, NC.

${ }^{2}$ Professor.

${ }^{3}$ Former Visiting Research Scientist.

${ }^{4}$ To whom reprint requests should be addressed; e-mail brian_jackson@ncsu.edu. quinquenervia $\mathrm{Cav}$.) that was amended with $4 \mathrm{~kg} \cdot \mathrm{m}^{-3}$ of dolomitic lime and a substrate made from ground tree ferns (Dicksonia squarosa Swartz.) was amended with 5.0 to $6.0 \mathrm{~g} \cdot \mathrm{L}^{-1}$ dolomite lime (Prasad and Maher, 2004) with no explanation of why the lime was added (it was not stated if the $\mathrm{pH}$ of the substrates used was lower than desired). Other work evaluating sawdust as successful container substrates have reported the incorporation of liming materials with no justification for doing so (Still et al., 1972). The addition of lime to substrates is probably based on tradition and common practice of using peat and bark-based substrates for the past three decades that require the addition of lime to increase $\mathrm{pH}$ for proper plant growth. The use of alternative (nonpeat or bark) substrates should be independently evaluated for their potential liming requirements as a result of initial $\mathrm{pH}$, buffering capacity, and so on.

In one study in which lime rates were evaluated, Hicklenton (1982) reported that the growth of Chrysanthemum morifolium Ramat. 'Mountain Peak', 'Goldstar', and 'Cir Bronze' in a sawdust substrate was unaffected by preplant substrate treatments, including increasing lime rates. However, limestone was not used as a single amendment but instead as a combination with multiple amendments that were applied. Therefore, plant response could not be attributed to (or explained by) the lime addition.

The use of pine tree substrates (PTS), which are produced from pine trees that are chipped and ground (with or without bark, limbs, needles, and so on) in a hammermill (Fain et al., 2006; Laiche and Nash, 1986; Wright and Browder, 2005), and clean chip residual $(\approx 40 \%$ pine wood, $50 \%$ bark, and $10 \%$ needles), which is produced from byproducts of the pine tree harvesting process (Boyer et al., 2006), has gained attention as alternative container substrates for greenhouse and nursery crop production. The interest in these wood-based substrates has generated many unanswered questions from nurserymen and scientists. Among the unknown issues that have emerged concerning the use of PTS are those relating to the limestone requirement and adjustment of $\mathrm{pH}$ for optimal plant growth.

In studies with PTS produced from delimbed loblolly pine trees (Jackson et al., 2008; Wright et al., 2006, 2008b), no lime was incorporated and $\mathrm{pH}$ was in the range of 5.5 to 6.4. Gruda and Schnitzler (2006) also used wood-based substrates without the addition of lime and the $\mathrm{pH}$ was in a range of 5.3 to 5.9 , an acceptable range for most greenhouse crops. In a study by Fain et al. (2008), three species of pine trees (P. taeda, $P$. elliottii, and $P$. palustris) were processed (including limbs and needles) to make three PTSs (one from each species) and all were amended with dolomitic limestone at 1.78 $\mathrm{kg} \cdot \mathrm{m}^{-3}$. The resulting $\mathrm{pH}(30 \mathrm{~d}$ after planting) of all substrates was between 6.9 and 7.2, which was above the optimum $\mathrm{pH}$ for growing 
annual vinca (Catharanthus roseus L.) which was the plant species used in the study. There was no treatment in their study without limestone. Other work with $100 \%$ PTS by Saunders et al. (2005) showed no advantage to amending $100 \%$ PTS with limestone for the growth of marigold.

More recent work (Jackson et al., 2009c; Wright et al., 2008a) has shown an advantage of grinding PTS coarsely (less expensive to grind) and adding peatmoss or aged PB to increase the amount of fine particles (less than $0.5 \mathrm{~mm}$ ) to provide adequate container capacity (amount of water held by the substrate in a container after drainage; container capacity is equivalent to waterholding capacity of a substrate). The additions of peatmoss or PB to PTS would likely necessitate limestone incorporation as a result of the low $\mathrm{pH}$ of those materials. Therefore, in the absence of well-defined recommendations for lime additions to PTS for $\mathrm{pH}$ adjustment and optimal plant growth - especially if peatmoss is incorporated - studies were conducted to evaluate the effect of limestone additions to $100 \%$ PTS and PTS amended with peatmoss on $\mathrm{pH}$ and the growth of two $\mathrm{pH}$-sensitive greenhouse crops.

\section{Materials and Methods}

Pine tree substrate was produced from trees harvested and delimbed on $19 \mathrm{Feb}$. 2007, chipped on $20 \mathrm{Feb}$. to $2.5 \mathrm{~cm} \times 2.5$ $\mathrm{cm} \times 0.25-\mathrm{cm}$ wood chips, and reduced further with a hammermill (Meadows Mills, Inc., North Wilkesboro, NC) passing through a 4.76-mm screen. From this material, three substrates were prepared: $100 \%$ PTS and PTS incorporated by volume with either $25 \%$ (PTS-25P) or 50\% (PTS-50P) peatmoss. Peat-lite (4 peat: 1 perlite v/v; Premier Tech, Quebec, Canada) was also used as a control. Each of the four substrates was amended with pulverized dolomitic limestone (89\% calcium $\mathrm{CO}_{3} \cdot \mathrm{MgCO}_{3}$, Pro pulverized Limestone; Old Castle Stone Products, Atlanta, GA) at the following rates: $0,1.78,3.56,5.35$, or $7.12 \mathrm{~kg} \cdot \mathrm{m}^{-3}$. Particle distribution of the limestone was as follows: $100 \%$ passed an $841-\mu \mathrm{m}$ (\#20) screen, $90 \%$ passed a $297-\mu \mathrm{m}$ (\#50) screen, and $80 \%$ passed a $150-\mu \mathrm{m}$ (\#100) screen. Substrates were also amended with calcium sulfate $\left(\mathrm{CaSO}_{4}\right)$ at $0.6 \mathrm{~kg} \cdot \mathrm{m}^{-3}$. On 4 June 2007, marigold plugs (144-tray, 2week-old seedings) were potted in $10-\mathrm{cm}$ square (1-L) containers filled with the substrates. Plants were glasshouse grown in Blacksburg, VA, with average day and night temperatures of 26 and $22{ }^{\circ} \mathrm{C}$, respectively. Plants in each substrate were overhead watered together as needed depending on need and weather conditions and never showed any symptoms of water stress. Blacksburg, VA, municipal water with an alkalinity of $36 \mathrm{mg} \cdot \mathrm{L}^{-1}$ was used. Plants were fertilized at each watering with $250 \mathrm{~mL}$ of a $300 \mathrm{mg} \cdot \mathrm{L}^{-1}$ nitrogen $(\mathrm{N})$ fertilizer solution from Peters 20N-4.4P-16.6K Peat-lite special (The Scotts Co., Marysville, $\mathrm{OH}$ ) containing $12 \%$ nitrate $\left(\mathrm{NO}_{3}-\mathrm{N}\right)$ and $8 \%$ ammonium
$\left(\mathrm{NH}_{4}-\mathrm{N}\right)$. Substrate solution was extracted weekly using the pourthrough method (Wright, 1986) and analyzed for $\mathrm{pH}$ and electrical conductivity (EC) using a Hanna HI 9811 instrument (Hanna Instruments, Woonsocket, RI). On 22 June, a growth index [(height + widest width + perpendicular width)/3] of each plant was taken, stems were severed at the substrate surface, fresh weight determined, dried for $5 \mathrm{~d}$ at $65{ }^{\circ} \mathrm{C}$, and dry weights were then recorded.

A similar experiment was initiated when plugs as described previously were transplanted on 17 July into the previously described substrates with the following pulverized dolomitic limestone additions: 0 , $0.89,1.78,3.56$, and $5.34 \mathrm{~kg} \cdot \mathrm{m}^{-3}$. Plant culture and data taken were as described previously, and the experiment was ended 3 Aug.

A third study was initiated 11 May 2007 with rooted cuttings of zonal geranium (Pelargonium $\times$ hortorum 'Rocky Mountain White') potted in round $15-\mathrm{cm}, 1.25-\mathrm{L}$ containers with the same substrates as described previously. Limestone rates were $0,1.75$, and $3.5 \mathrm{~kg} \cdot \mathrm{m}^{-3}$ and plants were irrigated and fertilized as described previously. The experiment was ended on 27 June.

All studies were arranged in a completely randomized design with six replications for the two marigold studies and eight for the geranium experiment. Data were subjected to analysis of variance with mean separation by Duncan's multiple range test using SAS (Version 9.1; SAS Institute, Cary NC) and regression analysis using SigmaPlot (Version 9.01; SPSS, Chicago, IL.).

\section{Results and Discussion}

The $\mathrm{pH}$ of all substrates in all studies was highest for $100 \%$ PTS and generally decreased as the proportion of peat increased (PTS-25P, PTS-50P, and PL) regardless of limestone rate (Table 1). The $\mathrm{pH}$ also increased with limestone additions, but the increase in $\mathrm{pH}$ was less responsive as the amount of peatmoss in the substrate increased from $25 \%$ to $50 \%$. For example, in the July marigold experiment (Table 1), the addition of $0.89 \mathrm{~kg} \cdot \mathrm{m}^{-3}$ limestone resulted in a $\mathrm{pH}$ increase of 1.3 units for $100 \%$ PTS, 0.8 for PTS-25P, 0.6 for PTS-50P, and 0.4 for $\mathrm{PL}$. This is an indication that the buffering capacity of PTS is lower than for peatmoss requiring more limestone-as the percent peat in PTS increases - to adjust the $\mathrm{pH}$ of PTS to 5.4 to 6.5 , a suitable range for most greenhouse crops (Nelson, 2003). For example, the amount of limestone required to reach this range, using the July $\mathrm{pH}$ data (Table 1), was $0.89 \mathrm{~kg} \cdot \mathrm{m}^{-3}(\mathrm{pH}$ 6.0) for $100 \%$ PTS, $3.56 \mathrm{~kg} \cdot \mathrm{m}^{-3}$ (pH 5.9) for PTS$25 \mathrm{P}, 5.35 \mathrm{~kg} \cdot \mathrm{m}^{-3}(\mathrm{pH} 5.9)$ for PTS-50P, and $5.35 \mathrm{~kg} \cdot \mathrm{m}^{-3}(\mathrm{pH} 5.5)$ for PL. The same trend was observed with the June marigold and the geranium data, although the $\mathrm{pH}$ range of 5.4 to 6.5 was not reached with geranium except for the $100 \%$ PTS and PTS-25P (at the 3.56$\mathrm{kg} \cdot \mathrm{m}^{-3}$ rate) because limestone levels did not go above $3.56 \mathrm{~kg} \cdot \mathrm{m}^{-3}$. In addition, adding even more limestone $\left(7.12 \mathrm{~kg} \cdot \mathrm{m}^{-3}\right)$ in the June marigold study increased $\mathrm{pH}$ very little above the $5.34-\mathrm{kg} \cdot \mathrm{m}^{-3}$ rate. The $\mathrm{pH}$ for PL and PTS-50P did not reach the desired $\mathrm{pH}$ in some cases, which could be the result of low water alkalinity $\left(36 \mathrm{mg} \cdot \mathrm{L}^{-1}\right)$ and the acidic reaction of the fertilizer $(200 \mathrm{~g}$ acidity $/ \mathrm{kg}$ fertilizer). The apparent low buffering capacity of PTS observed in this study is in contrast to peatmoss and PB substrates that have been shown to have high buffering capacities (Daniels and Wright, 1988; Nash et al., 1983).

Marigold growth. For the June experiment, at the $0-\mathrm{kg} \cdot \mathrm{m}^{-3}$ lime rate, $100 \%$ PTSgrown plants had higher shoot dry mass than the other treatments; PTS-25P was intermediate in shoot dry mass and PTS-50P and PL were lowest (Table 2). The lower pH (Table 1) of the substrates containing peat likely accounts for these plant growth differences. Applying limestone at the $1.78 \mathrm{~kg} \cdot \mathrm{m}^{-3}$ rate and above resulted in no differences in shoot dry mass between the substrate treatments showing that limestone improved the growth of PL and PTS when amended with peatmoss $(25 \%$ or $50 \%)$, especially at the $50 \%$ level, although $\mathrm{pH}$ with the peat-amended substrates was still lower than the 6.0 to 6.6 recommended for marigold culture (Argo and Fisher, 2002). Regression analysis validated a significant increase in shoot dry mass as lime rate increased for only PTS-50P. With the July experiment, $100 \%$ PTS and PTS25P, but not PTS-50P, had a higher shoot dry mass at the 0 and $0.89-\mathrm{kg} \cdot \mathrm{m}^{-3}$ lime rates than PL (Table 2). A limestone rate of $3.56 \mathrm{~kg} \cdot \mathrm{m}^{-3}$ was required to attain an equivalent plant dry weight in PL like in the PTS substrates. Also, only with PL and PTS-50P was there an overall growth response (regression analysis) to lime rate (Table 2). These data indicate that $100 \%$ PTS does not require limestone for the growth of marigold, but as the percent of peatmoss increases in PTS, there is a greater need for limestone additions to increase $\mathrm{pH}$ and optimize plant growth.

Geranium growth. At the $0-\mathrm{kg} \cdot \mathrm{m}^{-3}$ limestone rate, there was no difference in growth of geranium regardless of substrate (Table 2 ). Adding $1.78 \mathrm{~kg} \cdot \mathrm{m}^{-3}$ and $3.56 \mathrm{~kg} \cdot \mathrm{m}^{-3}$ limestone increased dry weight of geranium in substrates containing peatmoss, but not in $100 \%$ PTS, resulting in smaller plants for $100 \%$ PTS compared with plants grown in PTS-25P, PTS-50P, or in PL. The highest dry weight occurred at the $1.78-\mathrm{kg} \cdot \mathrm{m}^{-3}$ rate of limestone for PTS-25P, but $3.6 \mathrm{~kg} \cdot \mathrm{m}^{-3}$ of limestone was required for PTS-50P and PL (Table 2). These growth responses reflected changes in $\mathrm{pH}$ as a result of limestone additions (Table 1) because more limestone is required to increase substrate $\mathrm{pH}$ relative to the amount of peat present in the substrate. At any given limestone rate, $\mathrm{pH}$ decreases relative to the amount of peatmoss in the substrate. Higher limestone application rates for treatments containing peatmoss may have resulted in increased growth because $\mathrm{pH}$ (Table 1) for geranium did not reach the 6.0 
Table 1. Effect of dolomitic limestone rate on substrate $\mathrm{pH}$ of marigold and geranium grown in peat-lite (PL) and pine tree substrate (PTS) amended with peatmoss.

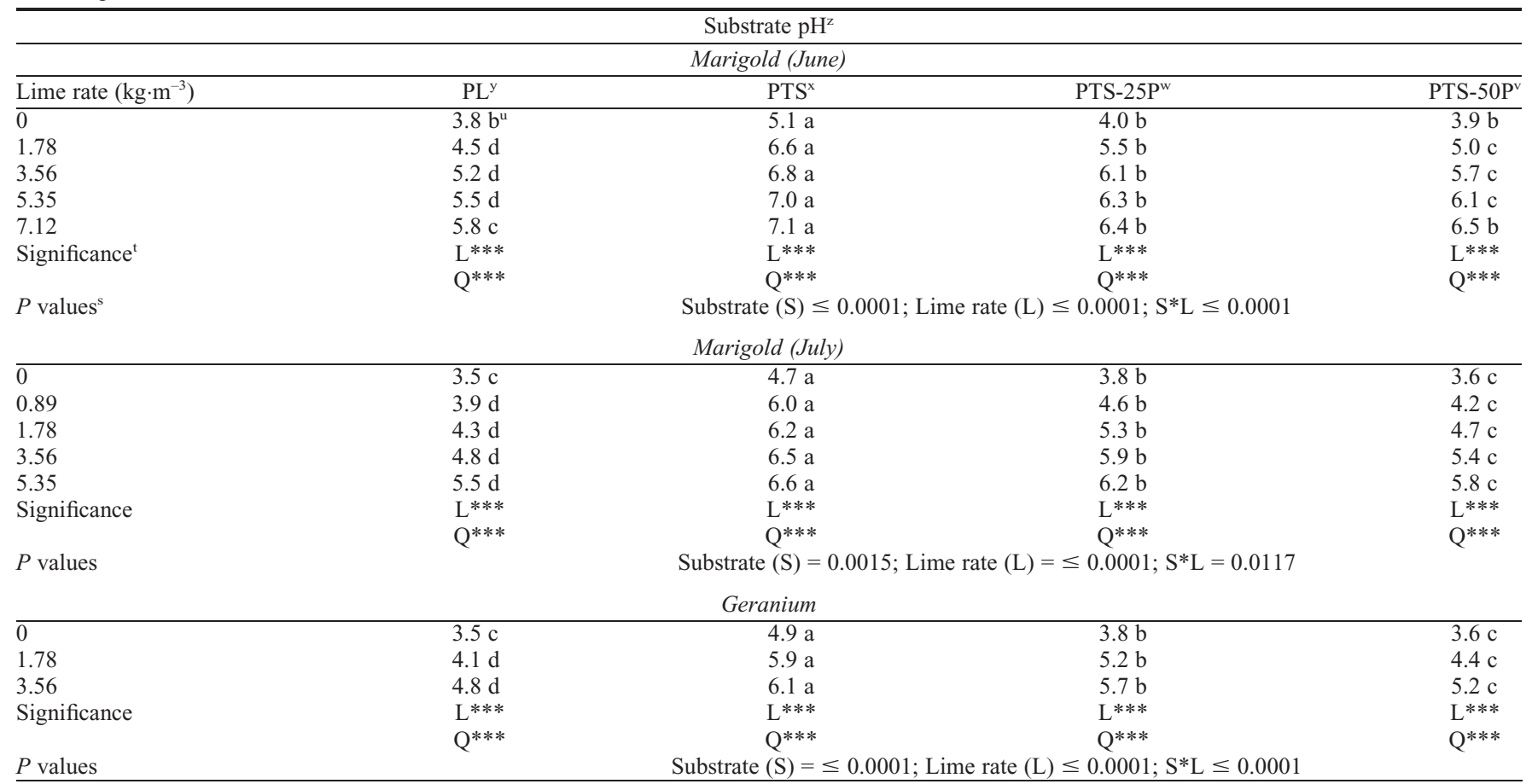

${ }^{\mathrm{p}} \mathrm{pH}$ of substrate solution determined on pourthrough extracts (Wright, 1986).

y PL composed of $80 \%$ peatmoss $/ 20 \%$ perlite $(\mathrm{v} / \mathrm{v})$.

${ }^{x}$ PTS produced from 12-year-old loblolly pine trees harvested at ground level, delimbed, chipped, and hammermilled to pass through a 4.76-mm screen.

wPTS-25P produced by amending PTS with $25 \%$ peatmoss (v/v).

vPTS-50P produced by amending PTS with $50 \%$ peatmoss (v/v).

"Mean separated within row by Duncan's multiple range test $(P \leq 0.05)$.

${ }^{\mathrm{t}} \mathrm{L}=$ linear; $\mathrm{Q}=$ quadratic response for $\mathrm{pH}$ at $* * *$, or $* * *$.

sonsignificant or significant at $* P \leq 0.05, * * 0.01$, or $* * * 0.001$, respectively.

Table 2. Effect of dolomitic limestone rate on shoot dry weight (g) of marigold and geranium grown in peat-lite (PL) and pine tree substrate (PTS) amended with peatmoss.

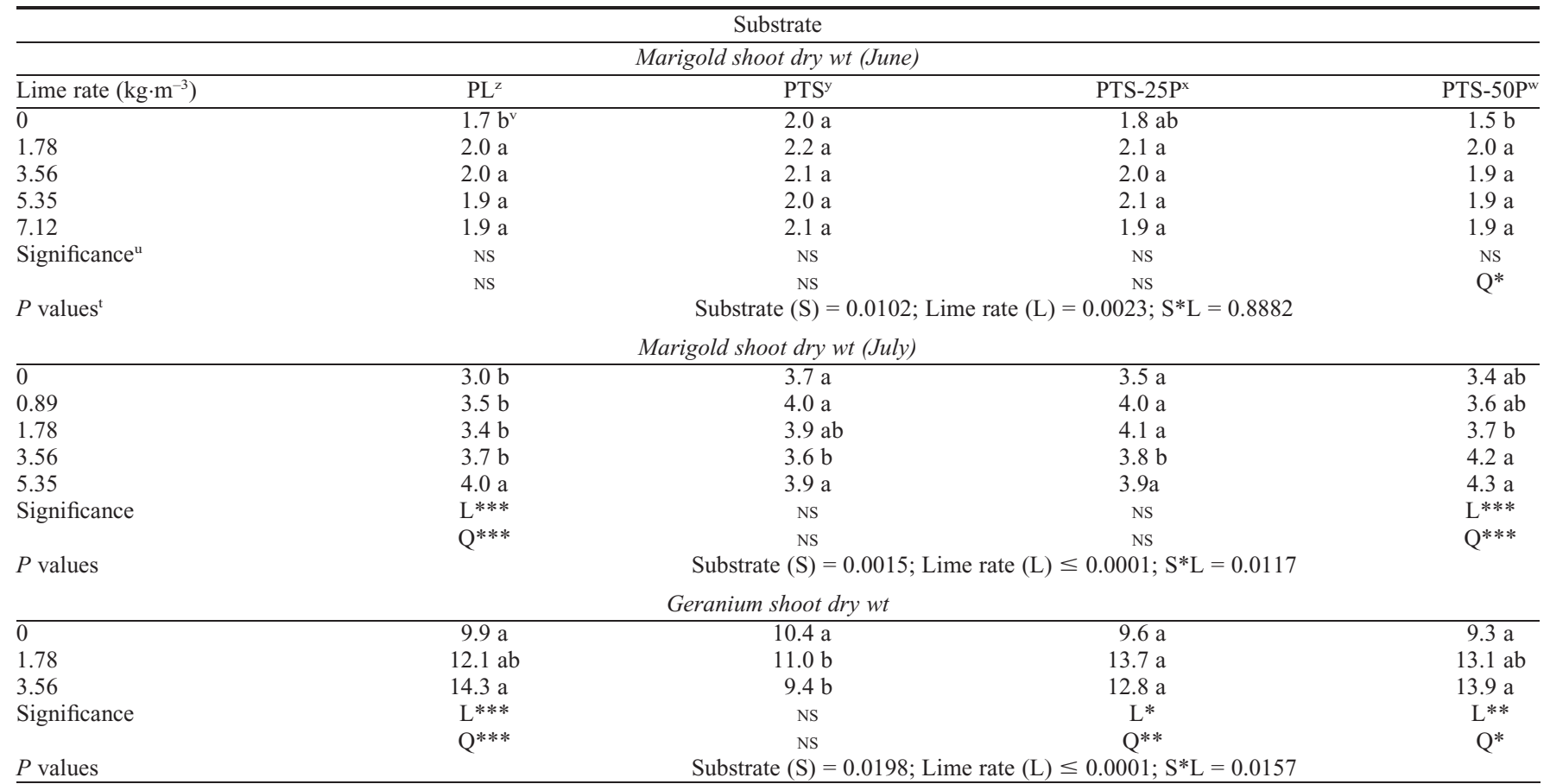

${ }^{2} \mathrm{PL}$ composed of $80 \%$ peatmoss $/ 20 \%$ perlite $(\mathrm{v} / \mathrm{v})$.

yPTS produced from 12-year-old loblolly pine trees harvested at ground level, delimbed, chipped, and hammermilled to pass through a 4.76-mm screen.

${ }^{\times}$PTS-25P produced by amending PTS with $25 \%$ peatmoss $(\mathrm{v} / \mathrm{v})$.

wPTS-50P produced by amending PTS with $50 \%$ peatmoss $(\mathrm{v} / \mathrm{v})$.

'Mean separated within row by Duncan's multiple range test $(P \leq 0.05)$.

" $\mathrm{L}=$ linear; $\mathrm{Q}=$ quadratic response for dry weight at $* * *$, or $* * *$.

'Nonsignificant or significant at $* P \leq 0.05, * * 0.01$, or $* * * 0.001$, respectively. 
alkalinity and the acidic or basic reaction of the fertilizer used. The effect of storage method and time on PTS as it relates to a drop in $\mathrm{pH}$ and limestone requirements to adjust those anticipated changes needs further investigation. Use of aged PTS for crop production may require different management in regard to $\mathrm{pH}$ than when using PTS produced from freshly harvested trees.

\section{Literature Cited}

Andrew, P.H. and P.A. Hammer. 2006. Response if zonal and ivy geraniums to root medium $\mathrm{pH}$. HortScience 41:1351-1355.

Argo, W.R. and P.R. Fisher. 2002. Understanding $\mathrm{pH}$ management for container-grown crops. Meister Pub., Willoughby, OH. p. 38.

Bohne, H. 2004. Growth of nursery crops in peatreduced and in peat-free substrates. Acta Hort. 644:103-106.

Boyer, C.R., G.B. Fain, C.H. Gilliam, T.V. Gallagher, H.A. Torbert, and J.L. Sibley. 2006. Clean chip residual: A new substrate component for container-grown plants. Proc. Southern Nursery Assn. Res. Conf. 51:22-25.

Conover, C.A. and R.T. Poole. 1983. Utilization of Melaleuca quinquenervia as a potting medium component for greenhouse production of foliage plants. HortScience 18:886-888.

Daniels, W.L. and R.D. Wright. 1988. Cation exchange properties of pine bark growing media as influenced by $\mathrm{pH}$, particle size, and cation species. J. Amer. Soc. Hort. Sci. 113: 557-560.

Fain, G.B., C.H. Gilliam, and J.L. Sibley. 2006. Processed whole pine trees as a substrate for container-grown plants. Proc. Southern Nursery Assn. Res. Conf. 51:59-61.

Fain, G.B., C.H. Gilliam, J.L. Sibley, and C.R. Boyer. 2008. Wholetree substrates derived from three species of pine in production of annual vinca. HortTechnology 18:13-17.

Gruda, N. 2005. Growth and quality of vegetables in peat substitute growing media. Postdoctoral Thesis. Humboldt University, Berlin, Germany.

Gruda, N., B.J. Rau, and R.D. Wright. 2009. Laboratory bioassay and greenhouse evaluation of pine tree substrate used as a container substrate. Eur. J. Hort. Sci. 74:73-78.

Gruda, N. and W.H. Schnitzler. 2006. Wood fiber substrates as a peat alternative for vegetable production. Eur. J. Wood Wood Prod. 64:347350.

Gruda, N., S.V. Tucher, and W.H. Schnitzler. 2000. $\mathrm{N}$-immobilization of wood fiber substrates in the production of tomato transplants [Lycoper- sicon lycopersicum (L.) Kerts. ex Farw.]. J. Appl. Bot. 74:32-37.

Hicklenton, P.R. 1982. Nitrogen and potassium nutrition in relation to growth and Andorra juniper in a sawdust-sphagnum peat medium. HortScience 17:355-358.

Jackson, B.E. 2008. Chemical, physical, and biological factors influencing nutrient availability and plant growth in a pine tree substrate. $\mathrm{PhD}$ Diss. Virginia Polytechnic Institute and State Univ., Blacksburg, VA.

Jackson, B.E. and R.D. Wright. 2007. Pine tree substrate: Fertility requirements for nursery and greenhouse crops. Comb. Proc. Intl. Plant Prop. Soc. 57:680-684.

Jackson, B.E., R.D. Wright, and M.M. Alley. 2009a. Comparison of fertilizer nitrogen availability, nitrogen immobilization, substrate carbon dioxide efflux, and nutrient leaching in peat-lite, pine bark, and pine tree substrates. HortScience 44:781-790.

Jackson, B.E., R.D. Wright, and J.R. Seiler. 2009b. Changes in chemical and physical properties of pine tree substrate and pine bark during longterm nursery crop production. HortScience 44:791-799.

Jackson, B.E., R.D. Wright, and M.C. Barnes. 2009c. Methods of constructing a pine tree substrate potting medium from various wood particle sizes, organic amendments, and sand for desired physical properties and plant growth. HortScience (accepted).

Jackson, B.E., R.D. Wright, and M.C. Barnes. 2008. Pine tree substrate, nitrogen rate, particle size, and peat amendment affects poinsettia growth and substrate physical properties. HortScience 43:2155-2161.

Laiche, A.J., Jr. and V.E. Nash. 1986. Evaluation of pine bark, pine bark with wood, and pine tree chips as components of a container plant growing media. J. Environ. Hort. 4:22-25.

Lumis, G.P. 1976. Using wood waste compost in container production. Amer. Nurseryman 163: $10-11,58-59$

Maas, E.F. and R.M. Adamson. 1982. Artificial media in horticulture-Their formulation and fertilization. Agriculture Canada. Publication 1726/E.

Nash, V.E., A.J. Laiche, Jr., and F.P. Rasberry. 1983. Effects of amending container growing media with dolomitic limestone on the growth of Photinia 'Fraseri'. Commun. Soil Sci. Plant Anal. 14:497-506.

Nelson, P.V. 2003. Greenhouse operation and management. 6th Ed. Prentice Hall, Englewood Cliffs, NJ.
Prasad, M. and M.J. Maher. 2004. Stability of peat alternatives and use of moderately decomposed peat as a structure builder in growing media. Acta Hort. 648:145-151.

Rau, B., B.E. Jackson, J.F. Browder, and R.D. Wright. 2006. Wood substrates derived from a variety of tree species affect plant growth. Proc. Southern Nursery Assn. Res. Conf. 51: 43-45.

Rippy, J.F.M., P.V. Nelson, D.L. Hesterberg, and E.J. Kamprath. 2007. Reaction times of twenty limestones. Commun. Soil Sci. Plant Anal. $38: 1775-1783$.

Riviere, L.M. and C. Milhau. 1983. The use of wood waste composts in the making of substrates for container crops. Acta Hort. 150:475489.

Saunders, T.N., R.D. Wright, and J.F. Browder. 2005. Chipped pine logs: A potential substrate for nursery and greenhouse crops. Proc. Southern Nursery Assn. Res. Conf. 50:112114.

Starck, J.R. and K. Lukaszuk. 1991. Effect of fertilizer nitrogen and potassium upon yield and quality of carnations growth in peat and sawdust. Acta Hort. 294:289-296.

Still, S., J.B. Gartner, and T.D. Hughes. 1972. Effect of sawdust age and nitrogen application on chrysanthemums grown in white oak sawdust media. Forest Prod. J. 22:111-114.

Worrall, R. 1976. The use of sawdust in potting mixes. International Plant Propagators' Society Combined Proc. 26:379-381.

Worrall, R.J. 1981. Comparison of composted hardwood and peat-based media for the production of seedlings, foliage and flowering plants. Scientia Hort. 15:311-319.

Wright, R.D. 1986. The pour-through nutrient extraction procedure. HortScience 21:227229.

Wright, R.D. and J.F. Browder. 2005. Chipped pine logs: A potential substrate for greenhouse and nursery crops. HortScience 40:15131515.

Wright, R.D., J.F. Browder, and B.E. Jackson. 2006. Ground pine chips as a substrate for container-grown woody nursery crops. J. Environ. Hort. 24:181-184.

Wright, R.D., B.E. Jackson, and M.C. Barnes. 2008a. Pine tree substrate construction for optimal water holding capacity and air space. Proc. Southern Nursery Assoc. Research Conf. 53:52-54.

Wright, R.D., B.E. Jackson, J.F. Browder, and J.G. Latimer. 2008b. Growth of chrysanthemum in ground pine trees requires additional fertilizer. HortTechnology 18:111-115. 